\title{
THE COMPARATIVE UTILIZATION OF CULTIVATED AND WEEDY UMBELLIFER SPECIES BY LARVAE OF THE BLACK SWALLOWTAIL BUTTERFLY, PAPILIO POLYXENES
}

\author{
By James M. Erickson ${ }^{1}$
}

Dept. of Entomology, Cornell University, Ithaca, New York 14850

\section{INTRODUCTION}

For many years, much of the emphasis in agriculture and plant breeding has been placed on increasing overall production (Allard 1960). This is because man is almost totally dependent on plants for his food. The things he eats come directly from plants or indirectly from herbivorous animals. Plants are also the major source, directly or indirectly, of most clothing, fuel, drugs, and construction materials.

The impact of insects on plants cannot be overemphasized. For example, some insects can be very successful in the biological control of weeds (Holloway 1964). Insects also have a great impact on the evolution and ecology of plants through their destruction of seeds, young seedlings, or the plants themselves (Breedlove and Ehrlich 1968, Janzen 1969, 1971). The relationships between the insect and the plants that we observe today are based upon millions of years of co-evolution. During the course of this evolution, plants have developed various mechanisms to resist insect attack. The majority of plant defenses can be classified as physical or chemical defenses (Stahl i 888). Plant physical defenses may include thickened cuticle (Tanton 1962, Feeny 1970) or hairs, spines, and thorns on the epidermis (Johnson 1953, Pearson 1958, Bernays and Chapman 1970), which interfere with the insects feeding. The high silica content of some plants or the crystalline materials in the leaves of many conifer species add a further physical barrier to insect attack (Merz I959, Pathak 1969).

Plants have also evolved a great array of chemical defenses, the so-called secondary substances. These include the alkaloids, glycosides, tannins, flavenoids, terpenoids, essential oils, and saponins, to name a few (Fraenkel 1969, Whittaker and Feeny 197I). Stahl ( I888) advanced the idea that these compounds evolved in plants as

\footnotetext{
1Present address: Dept. of Biological Science, California State University, Hayward, California 94542.

Manuscript received by the editor May 20, 1975.
} 
a defensive mechanism against insect and vertebrate herbivores, pathogens, and perhaps competitors. This view has been supported, as far as insects are concerned, by Dethier (1954, 1970), Thorsteinson (1960), Ehrlich and Raven (1965), Jermy (1966), Whittaker and Feeny (I97I), and Erickson and Feeny (1973). Much of the interaction between insects and these secondary substances is sensory in nature, and such substances may inhibit or deter feeding (Thorsteinson 1960, Gill and Lewis I97I), or may prove toxic to nonadapted larvae (Taylor 1959). Some plant species even synthesize and accumulate sterols which mimic insect molting secretions (Williams 1970). These phyto-ecdysones have been found in numerous fern species and prevent molting in insects feeding on such species (Whittaker and Feeny I97 I).

These secondary chemicals are not the only chemical means that plants have evolved to protect themselves from insect attack. Plant proteins are often deficient in some individual amino acids necessary for insect growth and development (Lord 1968, Boyd 1970). The nutritional quality or adequacy of the food plant is of utmost importance to a phytophagous insect (Friend 1958, Legay 1958). Aphids (Auclair et al. I957), beetles (Allen and Selman r955, I957), butterflies and moths (Hovanitz and Chang I962, Feeny 1970), grasshoppers (House I959, Dadd I96I), flies (Chapman 1969), and other insects (Gilmour I961, Levinson I962), have all been shown to exhibit quite variable feeding responses which in turn influence larval development, mortality, fecundity and fertility, when reared on different host plant species or on the same host plants grown under differing conditions or ages. Gordon (1959) has suggested that nutrient deficiencies in plants ". . . may be a result of natural selection of inedibility." The interaction between the nutritive adequacy of leaves and secondary chemistry has been demonstrated for oak trees and oak leaf tannins (Feeny 1968, 1969, I970).

Agriculturists and plant breeders have become aware of the problems that increased yield and palatability of crop species present in terms of the plant's inherent defensive mechanisms (Snelling I94I, Painter I951, Allard 1960, Briggs and Knowles 1967). The oldest record of inherent plant resistance to insect herbivores was by Havens ( 1792 ) in which he recognized the Hession fly resistance of the Underhill variety of wheat. However, scarcely 200 papers have dealt with this subject in the $\mathrm{I} 48$ year period from $\mathrm{I} 792$ to I940 (Snelling I94I). Generally, as plants species were domesticated and cultivated, various morphological and physiological changes 
occurred (Polunin 1960). Cultivated plant species are often larger in size, have larger seeds or seed sets, have more rapid and uniform seed germination, lose defensive structures such as hairs, thorns, or spines, and display improved palatability and nutritive content compared to their corresponding wild relatives.

The domestication of plants involves more than simply modifying the genetics of a species, because reciprocal adaptations between the domesticated (cultivated) species and the domesticator (man) are required. The domestication and cultivation of plants is in sorts a two way street; it may bring about ecological, social, and/or genetic changes in man as man has brought these changes to the plants. Selection for increased yield or increased productivity of the edible part of a crop species does not necessarily mean an increase in primary production. Above a certain point, increased yield must come at the sacrifice of some other adaptive use of energy (Cody 1966). As an example, generally increasing the yield of wheat decreases the amount of straw which is a fundamental part of the plant's selfproductive maintenance equipment (Odum 197I). Is it then possible, when breeding for increased palatability, yield, or nutritive content in cultivated plant species, to alter or decrease the inherent defensive mechanisms of the plants involved, be they physical, chemical, or both?

The purpose of this study is to examine this question in detail, utilizing the oligophagous butterfly, Papilio polyxenes, whose larvae feed on a variety of cultivated and wild or weedy species of the carrot family, the Umbelliferae (Chittenden 1909, Forbes 1960, and others). Many umbellifer species upon which these larvae feed, have been cultivated for centuries, primarily for spices and condiments for prepared foods (Buttery et al. 1968, French 1971, Kasting et al. 1972), and for medicinal or toxic drugs (Muenscher 195 I, Kingsbury 1964). Umbellifer plants are a major source of various vitamins (especially vitamin A) and minerals essential for proper growth in man (Lewis and Rubenstein 197I) as well as insects (Fraenkel 1953, Dadd 1957). Through studies of larval growth efficiency and food plant utilization, comparisons as to the relative adequacy of each host plant species, cultivated versus wild, can be determined.

\section{Methods and Materials}

Eggs of $P$. polyxenes were taken from the second generation of a culture founded from wild insects taken near Ithaca, New York and reared in the laboratory on carrot (Daucus carota). A minimum of 15 and a maximum of 20 eggs were placed on each of 32 umbellifer 
species: Io species of cultivated umbellifer and 22 species of wild or weedy umbellifers found in the Central New York area. The larvae were maintained on these species throughout larval development. Mature and uninjured leaves of the wild species were gathered in the field each day and the leaves of the cultivated umbellifers were collected from greenhouse reared plants. All leaves were sealed in plastic bags and offered to the larvae within 2 hours. Leaves were replaced and feces collected every 24 hours to prevent bacterial or fungal development. The larvae were reared in clear plastic boxes ( $9 \times 12 \times 4$ inches) (Tri-State Plastic Molding Co., Henderson, $\mathrm{Ky}$. ), in a climatically controlled chamber with the following parameters: temperature $22^{\circ}$ day, $18^{\circ}$ night, approximately $55 \%$ humidity, and a $16-8 \mathrm{LD}$ photoperiod.

For the purposes of examining larval energy and nutrient utilization, a minimum of 8 and a maximum of ro newly molted $4^{\text {th }}$ instar larvae were placed individually in glass petri dishes (Pyrex, Ioomm $\times 15 \mathrm{~mm}$ ) lined on the bottom with a piece of Whatman No. I filter paper. The ideal utilization study would, of course, encompass the entire life cycle as the efficiency of food utilization by the early instars is certainly of interest. The nutritional adequacy of the food plant material can be judged only by its ability to support growth in successive instars. There were, however, 2 reasons for utilizing only 4th instar larvae in this experiment. Since larvae of $P$. polyxenes consume approximately $0.1 \%$ of the total food ingested during larval development during the Ist instar, these minute quantities of food ingested and digested lead to exceptionally high error values and are therefore inaccurate. Similar results were obtained for the 2nd and 3 rd instars where the percentage of the total food consumed during larval development was $0.6 \%\left(\mathrm{~L}_{2}\right)$ and $2.8 \%\left(\mathrm{~L}_{3}\right)$. The ultimate instar was not included for the purposes of the energy utilization experiments due to a pre-pupal clearing of the gut in which a larva may lose up to $40 \%$ of his maximum wet weight within a 5 minute period. Once this occurs, there is no way to estimate the maximum larval weight which is necessary for various calculations to determine larval food utilization efficiencies. During the 4th instar, approximately io to $15 \%$ of the total food ingested during larval development is consumed. These larger amounts lead to more accurate weights which significantly reduce the statistical error.

All the individual larvae were placed in the same controlled temperature room, except for the period of time each day during which new food was offered to the larvae and the feces collected. The 
experimental larvae were fed the same leaves as the maintained cultures. These randomly collected leaves were split along the midrib, one half weighed and offered to the larvae and the other half weighed and used to determine the percent dry matter in the leaf material (Waldbauer 1960, 1964).

Besides the percent dry matter in the leaf material, the calorific and nitrogen content of the leaf material, the larvae, and the feces were determined. Calorific values of the larval food plants, feces, and larvae were determined by means of a Phillipson non-adiabatic microbomb calorimeter (Gentry and Wiegert Inst. Inc., Aiken, S.C.) (Phillipson 1964). The lyophilized leaf material, feces, and larvae were subjected to 3 replications for the determination of calorific values. The organic nitrogen content of the leaf material, the feces and the larvae, were determined either by the Kjeldahl method for total nitrogen (Williams 1964) or the microKjeldahl method (McKenzie and Wallace 1954). A minimum of 3 replicate samples was obtained for the larvae and the feces, as well as each host plant species.

The dry weight of food ingested by the larvae was estimated following the techniques of Waldbauer (1960, 1964), and Waldbauer and Fraenkel (196I) except that plant material was lyophilized instead of oven-dried. The dry weight of the food utilized ar assimilated was assumed to be the dry weight of the food ingested minus the dry weight of feces. An additional group of larvae were reared along with the experimental larvae, and these were sacrificed to determine the dry weights, and thus, the percentage of dry matter of the larvae. Indices of food utilization were determined following the methods of Waldbauer (1960, 1964, 1968). Many terms have been used both by ecologists and by physiologists to describe various measures and indices of food utilization and efficiency. Relationships between many of these terms are discussed by Kozlovsky (1968) and Waldbauer (1968).

As an index of digestibility, the ratio of the amount of food assimilated to the amount of food ingested, referred to as the 'Assimilation Efficiency' (Clark 1946, Odum 1957, Odum 1971), or the 'Coefficient of Digestibility' (Waldbauer 1964, 1968, House 1965), was used. In practice, this measure is only an approximation since the numerator (as determined by the usual gravimetric procedure) does not quite represent the amount of food actually assimilated (Waldbauer 1968). This slight error is due to the presence of metabolic wastes in addition to the undigested food in the feces (Lafon 195I). For this reason Waldbauer (1968) has suggested 
'Approximate Digestibility' as a less ambiguous term to describe this measure. However, Hiratsuka (1920) and Waldbauer (1964) point out that the uric acid content of the phytophagous insects is relatively low and that the difference between true and measured assimilation efficiencies is negligible.

The efficiency with which ingested food is converted to biomass is calculated by dividing the dry weight of food ingested into the dry weight gained by the larva during the instar. This index, referred to by the physiologists as the 'Efficiency of Conversion of Ingested Matter' (Waldbauer 1968) and by ecologists as the 'Ecological Growth Efficiency' (Gerking 1962, Odum 1971), is an overall measure of an animal's ability to utilize for growth the food ingested.

The efficiency with which digested food is converted to biomass is calculated by dividing the dry weight of food assimilated into the dry weight gained by the larva during the instar. This index, referred to by Waldbauer (I968) as the 'Efficiency of Conversion of Digested Matter' and by Gerking (1962) and Odum (197I) as the 'Tissue Growth Efficiency', decreases as the proportion of digested food metabolized for energy and maintenance of physiological functions increases (Waldbauer 1968).

In his classic work on accessary growth factors, Hopkins (I912) pointed out that absolute quantities cannot be used to compare the intake of food by animals growing at different rates. Valid comparisons could only be made on the basis of the rate of intake relative to the mean weight of the animal during the feeding period. Waldbauer (1964, 1968) working on this basis proposed the 'Consumption Index' calculated in this experiment as:

dry weight of food ingested

$\begin{gathered}\text { duration of } \\ \text { feeding period }\end{gathered} \times \quad \begin{gathered}\text { mean dry weight of the } \\ \text { animal during feeding period }\end{gathered}$

The mean weight of the animal is most accurately calculated from the area under its growth curve as determined by integration. A weighted average of daily weights will give an almost identical value if the growth curve is smooth (Waldbauer 1964). Such three variable equations are at times difficult to discuss, being included in the present work only for later comparison with other insect species (see Waldbauer 1968). From the equation, if 2 individual larvae ingest the same total amount of food, with the larva on the less nutritiously adequate food plant taking a great deal of time and gaining little biomass and the other larva on a more acceptable food plant gaining 
a great deal of biomass in a short time, the respective consumption indices may in fact be identical.

A more useful index for the growth rates of an individual larva is the mean dry weight added to larval biomass per day. This measure gives the investigator a much more accurate estimation as to the growth potential of the various umbellifer food plants.

For the purposes of food utilization and efficiency determinations, the experiment was concluded when the larvae molted into the ultimate instar. The larvae were then reared through to the adult stage on the same experimental plants that they fed upon before and during the utilization experiments. All resulting adult females were then utilized in various host plant selection experiments.

The data are generally presented as a mean and standard error for the larvae in any particular host plant treatment group. The various experimental parameters were subjected to one way analysis of variance (Guenther 1965, Snedecor and Cochran 1967) to determine differences among the various treatment groups. A typical T-test for 2 independent samples of unequal sizes utilizing a pooled variance (Guenther 1965) was used for analysis of the differences between cultivated and wild umbellifer species. Linear regression analyses were performed and the significance of the correlation coefficients was tested using a table of critical ' $r$ ' values (Snedecor and Cochran 1967). All statistical procedures were completed with the aid of a programable calculator (Olivetti programa IOI or microcomputer P602).

\section{RESULTS}

Various plant parameters differed greatly between cultivated (domesticated) and wild (weedy) species of Umbelliferae offered to the swallowtail larvae (Table I). The dry matter content of the leaf material was significantly lower $(\mathrm{P}<\mathrm{O}$.OI $)$ at a mean of approximately $\mathrm{I} 2.25 \%$ for the cultivated umbellifers than the wild umbellifer species which had a mean of about $21 \%$ dry matter. In terms of caloric content, no significant difference $(\mathrm{P}<.3)$ was found between the cultivated species, at a mean of about 4.1 I cal $/ \mathrm{mg}$ dry weight, and the wildly occurring species, at a mean of about 4.I 3 $\mathrm{cal} / \mathrm{mg}$ dry weight. The nitrogen content of the leaf material was significantly higher $(\mathrm{P}<0.05)$ in the cultivated species, averaging approximately $\mathrm{I} \%$ higher than the wild species in terms of total nitrogen. This value becomes significant when converted to protein content, as I \% nitrogen equals approximately $6.25 \%$ protein (Lord 1968). 
Table 1. Dry weight, calorific values and nitrogen content of various species of Umbelliferae offered to the larvae of the eastern black swallowtail, Papilio polyxenes, during the 4 th instar.

\begin{tabular}{|c|c|c|c|}
\hline Plant species & $\begin{array}{l}\text { Mean percent } \\
\text { dry material } \\
\text { in leaves } \\
\pm S^{\prime} 1,2\end{array}$ & $\begin{array}{l}\text { Mean calories } \\
\text { per milligram } \\
\text { dry weight of } \\
\text { leaf material } \\
\pm \text { SE } 1,3\end{array}$ & $\begin{array}{l}\text { Mean percent } \\
\text { of nitrogen } \\
\text { in leaf material } \\
\pm \mathrm{SE}^{1,4} 4\end{array}$ \\
\hline
\end{tabular}

Cultivated species

Anethum graveolens Dill

$\begin{array}{rlrl}8.58 & \pm 0.15 & 4.00 \pm 0.11 & 5.48 \pm 0.27 \\ N & =20 & & \\ 15.90 & \pm 0.48 & 3.94 \pm 0.21 & 3.57 \pm 0.10 \\ N & =28 & & \\ 15.10 & \pm 0.37 & 4.31+0.10 & 4.81 \pm 0.16 \\ N & =34 & & \\ 11.63 & \pm 0.36 & 4.36 \pm 0.07 & 4.93 \pm 0.31 \\ N & =36 & & \\ 8.96 & \pm 0.29 & 4.05 \pm 0.22 & 5.31 \pm 0.09 \\ N & =42 & & \\ 7.64 & \pm 0.16 & 4.01 \pm 0.09 & 5.45 \pm 0.31 \\ N & =16 & & \\ 15.27 & \pm 0.68 & 4.11 \pm 0.26 & 2.80 \pm 0.17 \\ N & =29 & & \\ 16.00 & \pm 0.27 & 4.44 \pm 0.37 & 5.12 \pm 0.40 \\ N & =33 & & \\ 8.83 & \pm 0.21 & 4.03 \pm 0.17 & 5.52 \pm 0.19 \\ N & =24 & & \\ 14.65 & \pm 0.37 & 3.83 \pm 0.09 & 2.83 \pm 0.07 \\ N & =37 & & \end{array}$

Apium graveolens

Celery

Carum carvi

Caraway

Coriandrum sativum

Coriander

Daucus carota

Foen iculum vulgare

Fennel

Ligusticum scothicum

Scotch lovage

Pastinaca sativa

Parsnip

Petroselinum crispum

Parsley

Pimpinella anisum

Anise

Wild species

Aegopodium podagraria Goutweed

$21.87 \pm 0.22$

$4.42 \pm 0.13$

$4.60 \pm 0.31$

Aegopodium varigatum

Goutweed

$N=22$

$20.73 \pm 0.31$

$N=39$

$4.30 \pm 0.22$

$3.03 \pm 0.11$

Aethusa cynapium

Fools parsley

$11.56 \pm 0.23$

$4.06 \pm 0.17$

$3.68 \pm 0.23$ 
Table 1. Continued.

\begin{tabular}{|c|c|c|c|}
\hline Plant species & $\begin{array}{l}\text { Mean percent } \\
\text { dry material } \\
\text { in leaves } \\
\pm S^{1}, 2\end{array}$ & $\begin{array}{l}\text { Mean calories } \\
\text { per milligram } \\
\text { dry weight of } \\
\text { leaf material } \\
\pm \mathrm{SE}^{2}, 3\end{array}$ & $\begin{array}{l}\text { Mean percent } \\
\text { of nitrogen } \\
\text { in leaf material } \\
\pm \mathrm{SE}^{2}, 4\end{array}$ \\
\hline$\frac{\text { Angel ica atropurpurea }}{\text { Angelica }}$ & $\begin{aligned} 25.22 & \pm 0.41 \\
N & =25\end{aligned}$ & $4.25 \pm 0.06$ & $5.12 \pm 0.09$ \\
\hline Angelica triquinata & $\begin{aligned} 18.49 & \pm 0.65 \\
N & =36\end{aligned}$ & $4.27 \pm 0.19$ & $4.56 \pm 0.33$ \\
\hline$\frac{\text { Cicuta }}{\text { Bulb bealbifera }}$ & $\begin{aligned} 18.17 & \pm 0.42 \\
N & =17\end{aligned}$ & $4.15 \pm 0.17$ & $3.64 \pm 0.08$ \\
\hline$\frac{\text { Cicuta }}{\text { Water haculata }}$ & $\begin{aligned} 19.20 & \pm 0.62 \\
N & =27\end{aligned}$ & $4.19 \pm 0.19$ & $3.67 \pm 0.25$ \\
\hline Coelopleurum lucidum & $\begin{aligned} 18.23 & \pm 0.66 \\
N & =42\end{aligned}$ & $4.13 \pm 0.23$ & $3.21 \pm 0.07$ \\
\hline$\frac{\text { Conium maculatum }}{\text { Poison hemlock }}$ & $\begin{aligned} 20.98 & \pm 0.55 \\
N & =53\end{aligned}$ & $4.31 \pm 0.21$ & $3.44 \pm 0.15$ \\
\hline$\frac{\text { Cryptotaenia canadensis }}{\text { Honewort }}$ & $\begin{aligned} 16.96 & \pm 0.50 \\
N & =16\end{aligned}$ & $4.07 \pm 0.11$ & $4.25 \pm 0.29$ \\
\hline Daucus carota & $\begin{aligned} 19.73 & \pm 0.36 \\
N & =24\end{aligned}$ & $3.95 \pm 0.21$ & $3.04 \pm 0.06$ \\
\hline$\frac{\text { Heracleum }}{\text { Cow parsnip }} \frac{\text { maximum }}{p}$ & $\begin{aligned} 24.66 & \pm 0.69 \\
N & =24\end{aligned}$ & $3.97 \pm 0.11$ & $4.71 \pm 0.10$ \\
\hline$\frac{\text { Heracleum }}{\text { Cow parsniphondylium }}$ & $\begin{aligned} 23.67 & \pm 0.72 \\
N & =34\end{aligned}$ & $4.10 \pm 0.23$ & $3.61 \pm 0.27$ \\
\hline$\frac{\text { Imperatoria ostruthium }}{\text { Masterwort }}$ & $\begin{aligned} 21.99 & \pm 0.96 \\
N & =24\end{aligned}$ & $4.13 \pm 0.17$ & $4.26 \pm 0.31$ \\
\hline$\frac{\text { Levisticum officinale }}{\text { Lovage }}$ & $\begin{aligned} 20.48 & \pm 0.23 \\
N & =26\end{aligned}$ & $3.98 \pm 0.27$ & $3.70 \pm 0.16$ \\
\hline$\frac{\text { Pastinaca sativa }}{\text { Parsnip }}$ & $\begin{aligned} 19.34 & \pm 0.36 \\
N & =20\end{aligned}$ & $4.19 \pm 0.23$ & $5.12 \pm 0.07$ \\
\hline$\frac{\text { Pseudotaenidia montana }}{\text { Mountain pimpernel }}$ & $\begin{aligned} 31.41 & \pm 0.49 \\
N & =23\end{aligned}$ & $4.01 \pm 0.16$ & $1.54 \pm 0.07$ \\
\hline$\frac{\text { Sium }}{\text { Water suave }}$ & $\begin{aligned} 7.38 & \pm 0.21 \\
N & =27\end{aligned}$ & $4.06 \pm 0.31$ & $3.80 \pm 0.13$ \\
\hline
\end{tabular}


Table 1. Continued.

\begin{tabular}{|c|c|c|c|}
\hline Plant species & $\begin{array}{l}\text { Mean percent } \\
\text { dry material } \\
\text { in leaves } \\
\pm S^{1}, 2\end{array}$ & $\begin{array}{l}\text { Mean calories } \\
\text { per milligram } \\
\text { dry weight of } \\
\text { leaf material } \\
\pm \text { SE }^{1,3}\end{array}$ & $\begin{array}{l}\text { Mean percent } \\
\text { of nitrogen } \\
\text { in leaf material } \\
\pm \mathrm{SE}^{1}, 4\end{array}$ \\
\hline$\frac{\text { Taenidia intergerrima }}{\text { Yellow pimpernel }}$ & $\begin{aligned} 24.31 & \pm 0.64 \\
N & =30\end{aligned}$ & $3.97 \pm 0.13$ & $2.81 \pm 0.20$ \\
\hline$\frac{\text { Thaspium }}{\text { Meadow parbinode }}$ & $\begin{aligned} 30.79 & \pm 0.58 \\
N & =28\end{aligned}$ & $3.93 \pm 0.23$ & $2.22 \pm 0.19$ \\
\hline$\frac{\text { Zizia }}{\text { Heart }} \frac{\text { aptera }}{\text { shaped a lexanders }}$ & $\begin{aligned} 19.80 & \pm 0.73 \\
N & =27\end{aligned}$ & $4.31 \pm 0.17$ & $3.21 \pm 0.22$ \\
\hline$\frac{\text { Zizia }}{\text { Golden }} \frac{\text { aurea }}{\text { alexanders }}$ & $\begin{aligned} 23.53 & \pm 0.16 \\
N & =18\end{aligned}$ & $4.25 \pm 0.19$ & $4.23 \pm 0.11$ \\
\hline
\end{tabular}

'The significance values of the ' $T$ ' statistic with 30 df are: $0.05=2.042$, $0.01=2.750$.

$2_{T}=5.666$

${ }^{3} \mathrm{~T}=0.422$

${ }^{4} T=2.349$

The larvae reared on the 32 umbellifer species all ingested approximately the same total amount of food, averaging about I44 dry weight $\mathrm{mg}$, during the 4 th instar $(\mathrm{P}<.3$ ) (Table 2). Generally, all larvae completed the 4 th instar in about 3 days $(\mathrm{P}<.3)$, thus the rate of food consumed also did not vary significantly $(T=0.247$, $\mathrm{P}<.4$ ). The proportion of ingested food which was digested and assimilated ('Approximate Digestibility') averaged approximately $53 \%$ for the larvae reared on the cultivated umbellifer species and about $47 \%$ for the larvae reared on the wild umbellifer species $(\mathrm{P}<0.05)$. The efficiency with which ingested food was converted to larval biomass ranged from approximately $25 \%$ for the larvae reared on the cultivated umbellifer species to approximately $19 \%$ for the larvae reared on the wild umbellifer species $(P<0.05)$.

The efficiency of conversion of digested food into larval biomass did not vary significantly between the two groups of plants tested and averaged approximately $45 \%$ in all cases $(P<.2)$ (Table 3 ). Individual larvae gained on the average approximately ro dry wt. mg more on cultivated umbellifer species than the larvae reared on wild umbellifer species, during the $4^{\text {th }}$ instar $(\mathrm{P}<0.05)$. This 
figure converts to approximately 80 wet wt. $\mathrm{mg}$ which for a normal 4th instar caterpillar comprises about $20 \%$ of its maximum net weight. In terms of the consumption index, or the rate, corrected for larval weight, at which food enters the gut, both groups of larvae were ingesting at approximately the same rate $(P<. I)$, although larvae reared on wild umbellifer species did display a slightly higher consumption (Table 3). In terms of larval weight gained per day, the larvae reared on the cultivated umbellifer species gained about I I.6 dry wt. mgs per day whereas larvae reared on the wild species averaged on the whole about 8.7 dry wt. mgs per day $(P<0.05)$.

\section{Discussion}

One of the major concerns of modern ecology is the description and explanation of the energetic relationships between and within various communities. A knowledge of the food and energy utilization of insects is thus of particular importance to ecology since insects exert a substantial influence and impact on almost all terrestrial communities. Energy utilization studies and their ecological significance have been extensively reviewed (Englemann 1966, Phillipson I966, and others).

Adaptive nutritional differences in host plants must be sought on a quantitative level and meaningful comparisons of food utilization and nutrition will not emerge until quantitative studies are carried out (Erickson 1972). The determination of absolute requirements for dietary constituents depends upon the measurement of food or nutrient intake. Differences in food utilization efficiency can be demonstrated only by measuring intake and growth. Measurement of the food intake and the utilization of this food elucidates to a great degree the physiological processes occurring in an insect since patterns of utilization may be different although food sources are similar in their ability to support growth. For instance, low food intake may be offset by a high utilization of ingested or digested food and a very high food intake may well lead to a very low efficiency in the utilization of ingested or digested food.

In this experiment, the larvae of the black swallowtail, $P$. poly $x$ enes, display a marked differential growth rate when reared on cultivated versus weedy umbellifer species. Larvae reared on cultivated umbellifer species gained approximately $25 \%$ more weight during the 4 th instar than larvae reared on the wild or weedy umbellifer species (Table 3 ). Since the larvae were generally from the same genetic background and were reared under similar conditions, 
Table 2. The utilization of food by 4 th instar larvae of the black swallowtail

P. polyxenes, when reared on various species of cultivated and wild umbellifer food plants (Mean $\pm S E$ ). Common names of plant species can be found in Table 1 .

\begin{tabular}{|c|c|c|c|c|}
\hline Plant species & $\begin{array}{l}\text { Total food } \\
\text { ingested } \\
\text { (mg) } 1,2\end{array}$ & $\begin{array}{l}\text { Duration of } \\
4 \text { th instar } \\
\text { (Days) } 1,3\end{array}$ & $\begin{array}{l}\text { Approximate } \\
\text { digesti- } \\
\text { bility } 1,4\end{array}$ & $\begin{array}{l}\text { Efficiency } \\
\text { conversion } \\
\text { ingested } \\
\text { matter } 1,5\end{array}$ \\
\hline \multicolumn{5}{|l|}{ Cultivated species } \\
\hline Anethum graveolens & $112.91 \pm 8.26$ & $3.06 \pm 0.17$ & $55.86 \pm 2.09$ & $37.04 \pm 2.86$ \\
\hline Apium graveolens & $196.14 \pm 5.48$ & $2.99 \pm 0.06$ & $64.94 \pm 0.89$ & $21.45 \pm 0.57$ \\
\hline Carum carvi & $147.74 \pm 3.86$ & $2.90 \pm 0.03$ & $54.74 \pm 0.77$ & $27.88 \pm 0.36$ \\
\hline Coriandrum sativum & $191.09 \pm 4.70$ & $2.97 \pm 0.02$ & $46.33 \pm 0.98$ & $22.88 \pm 0.66$ \\
\hline Daucus carota & $150.63 \pm 5.92$ & $3.55 \pm 0.09$ & $55.07 \pm 2.00$ & $29.99 \pm 0.96$ \\
\hline Foenicul um vulgare & $117.90 \pm 12.15$ & $3.07 \pm 0.19$ & $56.49 \pm 2.02$ & $31.97 \pm 1.70$ \\
\hline Ligusticum scothicum & $120.95 \pm 5.07$ & $2.98 \pm 0.01$ & $48.11 \pm 1.53$ & $14.05 \pm 0.81$ \\
\hline Pastinaca sativa & $145.15 \pm 6.16$ & $3.33 \pm 0.07$ & $49.64 \pm 0.70$ & $25.23 \pm 0.23$ \\
\hline Petrosel inum crispum & $129.82 \pm 5.76$ & $3.47 \pm 0.06$ & $57.99 \pm 2.86$ & $31.04 \pm 1.48$ \\
\hline Pimpinella anisum & $123.96 \pm 6.21$ & $3.07 \pm 0.17$ & $43.55 \pm 1.48$ & $14.20 \pm 0.93$ \\
\hline \multicolumn{5}{|l|}{ Wild species } \\
\hline Aegopodium podagraria & $154.21 \pm 5.43$ & $2.82 \pm 0.05$ & $48.02 \pm 2.58$ & $21.14 \pm 1.23$ \\
\hline Aegopodium varigatum & $170.92 \pm 4.61$ & $2.93 \pm 0.06$ & $52.40 \pm 1.13$ & $24.81 \pm 0.61$ \\
\hline Aethusa cynapium & $168.15 \pm 6.24$ & $2.97 \pm 0.01$ & $47.16 \pm 1.06$ & $18.52 \pm 1.74$ \\
\hline Angelica atropurpurea & $186.69 \pm 13.14$ & $2.86 \pm 0.06$ & $60.15 \pm 3.57$ & $18.65 \pm 1.41$ \\
\hline Angelica triquinata & $86.38 \pm 6.39$ & $3.09 \pm 0.26$ & $42.63 \pm 1.33$ & $29.51 \pm 1.35$ \\
\hline Cicuta bulbifera & $122.37 \pm 9.82$ & $2.86 \pm 0.23$ & $47.68 \pm 3.87$ & $14.80 \pm 0.72$ \\
\hline
\end{tabular}


Table 2. Centinued.

\begin{tabular}{|c|c|c|c|c|}
\hline Plant species & $\begin{array}{l}\text { Total food } \\
\text { ingested } \\
\text { (mg) } 1,2\end{array}$ & $\begin{array}{l}\text { Duration of } \\
4+b \text { instar } \\
\text { (Days) } 1,3\end{array}$ & $\begin{array}{l}\text { Approximate } \\
\text { digesti- } \\
\text { bility } 4,4\end{array}$ & $\begin{array}{l}\text { Efficiency of } \\
\text { conversion of } \\
\text { ingested } \\
\text { matter } 1,5\end{array}$ \\
\hline Cicuta maculata & $157.38 \pm 14.29$ & $2.69 \pm 0.09$ & $46.27 \pm 2.56$ & $20.32 \pm 1.60$ \\
\hline Coeloplourum lucidum & $118.70 \pm 3.39$ & $2.91 \pm 0.06$ & $45.80 \pm 1.22$ & $14.58 \pm 0.58$ \\
\hline Conium maculatum & $133.23 \pm 13.34$ & $3.28 \pm 0.12$ & $49.43 \pm 3.82$ & $18.40 \pm 0.96$ \\
\hline Cryptotaenia canadensis & $100.58 \pm 7.32$ & $2.88 \pm 0.19$ & $46.43 \pm 3.89$ & $18.29 \pm 2.12$ \\
\hline Daucus carota & $136.33 \pm 13.99$ & $3.20 \pm 0.09$ & $51.48 \pm 3.02$ & $13.99 \pm 0.65$ \\
\hline Heracleum maximum & $221.30 \pm 15.81$ & $2.97 \pm 0.04$ & $70.03 \pm 1.77$ & $11.86 \pm 0.84$ \\
\hline Heracleum sphondylium & $217.62 \pm 14.37$ & $2.97 \pm 0.04$ & $67.64 \pm 1.37$ & $13.91 \pm 0.49$ \\
\hline Imperatoria ostruthium & $142.90 \pm 8.96$ & $3.48 \pm 0.07$ & $45.16 \pm 1.20$ & $18.36 \pm 0.57$ \\
\hline Levisticum officinale & $120.57 \pm 9.27$ & $3.67 \pm 0.13$ & $39.85 \pm 1.06$ & $17.09 \pm 1.07$ \\
\hline Pastinaca sativa & $88.42 \pm 9.19$ & $3.02 \pm 0.01$ & $52.40 \pm 2.68$ & $18.51 \pm 1.31$ \\
\hline Pseudotaenidia montana & $152.55 \pm 14.63$ & $4.62 \pm 0.26$ & $22.41 \pm 2.65$ & $14.05 \pm 1.34$ \\
\hline Slum suave & $118.37 \pm 4.55$ & $3.15 \pm 0.02$ & $49.11 \pm 0.90$ & $31.08 \pm 1.14$ \\
\hline Taenidla Integerrima & $142.56 \pm 15.64$ & $2.84 \pm 0.09$ & $45.13 \pm 4.10$ & $16.88 \pm 1.51$ \\
\hline Thaspium barbinode & $161.70 \pm 6.03$ & $4.41 \pm 0.26$ & $28.10 \pm 2.12$ & $14.42 \pm 1.88$ \\
\hline Zizia aptera & $138.73 \pm 4.77$ & $2.91 \pm 0.06$ & $44.20 \pm 1.87$ & $29.11 \pm 0.74$ \\
\hline Zizla aurea & $140.04 \pm 9.55$ & $2.69 \pm 0.07$ & $34.50 \pm 1.33$ & $19.29 \pm 0.80$ \\
\hline
\end{tabular}

'The significance values of the ' $T$ ' statistic with $30 \mathrm{df}$ are: $0.05= \pm 2.042,0.01=$ \pm 2.750 .

${ }^{2} \mathrm{~T}=0.079$

$3_{T}=0.058$

${ }^{4} \mathrm{~T}=2.103$

${ }^{5} \mathrm{~T}=2.615$ 
Table 3. The utilization of food by 4th instar larvae of the black swallowtall, P. polyxenes, when reared on various species of cultivated and wild umbellifer food plants (Mean $\pm S E$ ). Common names of plant species can be found in Table 1.

\begin{tabular}{|c|c|c|c|c|}
\hline Plant species & $\begin{array}{l}\text { Efficiency } \\
\text { of conversion } \\
\text { of digested } \\
\text { matter } 1,2\end{array}$ & $\begin{array}{l}\text { Larval wt; } \\
\text { gain (mg) } 1,3\end{array}$ & $\begin{array}{l}\text { Consumption } \\
\text { index } 1,4\end{array}$ & $\begin{array}{l}\text { Larval wt. } \\
\text { gain (mg } \\
\text { dry vt,! } \\
\text { dayl } 1,5\end{array}$ \\
\hline \multicolumn{5}{|l|}{ Cultivated species } \\
\hline Anethum graveolens & $69.03 \pm 4.93$ & $40.64 \pm 2.47$ & $1.53 \pm 0.10$ & $13.66 \pm 1.26$ \\
\hline Apium graveolens & $33.27 \pm 0.98$ & $41.97 \pm 1.12$ & $2.65 \pm 0.08$ & $14.11 \pm 0.56$ \\
\hline Carum carvi & $50.99 \pm 1.05$ & $41.10 \pm 0.76$ & $2.12 \pm 0.03$ & $14.17 \pm 0.25$ \\
\hline Coriandrum sativum & $49.41 \pm 1.15$ & $43.57 \pm 0.95$ & $2.55 \pm 0.08$ & $14.66 \pm 0.38$ \\
\hline Daucus carota & $54.04 \pm 2.76$ & $45.03 \pm 1.78$ & $1.62 \pm 0.06$ & $12.66 \pm 0.30$ \\
\hline Foeniculum vulgare & $57.38 \pm 4.32$ & $36.59 \pm 2.43$ & $1.75 \pm 0.15$ & $12.17 \pm 1.13$ \\
\hline Ligusticum scothicum & $29.36 \pm 1.97$ & $17.15 \pm 1.22$ & $3.39 \pm 0.13$ & $5.77 \pm 0.41$ \\
\hline Pastinaca sativa & $50.91 \pm 0.80$ & $36.61 \pm 1.54$ & $2.00 \pm 0.05$ & $11.04 \pm 0.53$ \\
\hline Petroselinum crispum & $54.40 \pm 4.12$ & $40.64 \pm 3.19$ & $1.54 \pm 0.09$ & $11.66 \pm 0.82$ \\
\hline Pimpinella anisum & $32.52 \pm 1.63$ & $17.84 \pm 1.86$ & $3.36 \pm 0.23$ & $5.92 \pm 0.76$ \\
\hline
\end{tabular}

Wild species

\begin{tabular}{lllll} 
Aegopodium podagrarla & $45.65 \pm 4.55$ & $32.67 \pm 2.33$ & $2.77 \pm 0.26$ & $11.66 \pm 0.93$ \\
Aegopodium varigatum & $47.44 \pm 1.15$ & $42.30 \pm 0.90$ & $2.38 \pm 0.09$ & $14.45 \pm 0.38$ \\
\hline Aethusa cynapium & $39.29 \pm 1.43$ & $31.17 \pm 1.83$ & $2.99 \pm 0.11$ & $10.49 \pm 0.59$ \\
\hline Angelica atropurpurea & $32.69 \pm 3.25$ & $33.98 \pm 2.33$ & $2.97 \pm 0.23$ & $11.92 \pm 0.80$ \\
Angelica triquinata & $69.23 \pm 2.29$ & $25.59 \pm 2.32$ & $1.74 \pm 0.20$ & $8.28 \pm 0.12$ \\
Cicuta bulbifera & $33.12 \pm 2.68$ & $17.76 \pm 1.63$ & $3.48 \pm 0.36$ & $6.36 \pm 0.63$
\end{tabular}


Table 3. Continued.

\begin{tabular}{|c|c|c|c|c|}
\hline Plant species & $\begin{array}{l}\text { Efficiency } \\
\text { of conversion } \\
\text { of digested } \\
\text { matterl, } 2\end{array}$ & $\begin{array}{l}\text { Larval wt. } \\
\text { gain }(m g)^{i}, 3\end{array}$ & $\begin{array}{l}\text { Consumption } \\
\text { index }{ }^{1}, 4\end{array}$ & $\begin{array}{l}\text { Larval wt. } \\
\text { gain (mg } \\
\text { dry wt.l } \\
\text { day) } 1,5\end{array}$ \\
\hline Cicuta maculata & $45.29 \pm 4.67$ & $31.04 \pm 2.48$ & $2.92 \pm 0.19$ & $11.46 \pm 0.66$ \\
\hline Coelopleurum lucidum & $31.76 \pm 1.52$ & $17.32 \pm 0.87$ & $3.37 \pm 0.10$ & $5.78 \pm 0.45$ \\
\hline Conium maculatum & $39.53 \pm 3.58$ & $23.79 \pm 1.65$ & $2.41 \pm 0.12$ & $7.33 \pm 0.60$ \\
\hline Cryptotaenla canadensis & $42.31 \pm 5.38$ & $17.76 \pm 1.89$ & $2.88 \pm 0.30$ & $6.60 \pm 1.02$ \\
\hline Daucus carota & $28.00 \pm 2.30$ & $19.05 \pm 2.15$ & $3.23 \pm 0.20$ & $5.98 \pm 0.68$ \\
\hline Heracleum maximum & $17.14 \pm 1.50$ & $25.64 \pm 1.69$ & $4.11 \pm 0.25$ & $8.65 \pm 0.60$ \\
\hline Heracleum sphondy llum & $20.67 \pm 0.99$ & $29.84 \pm 1.34$ & $3.99 \pm 0.19$ & $10.05 \pm 0.46$ \\
\hline Imperatoria ostruthium & $40.82 \pm 1.50$ & $26.22 \pm 1.76$ & $2.40 \pm 0.06$ & $7.53 \pm 0.50$ \\
\hline Levisticum officinale & $41.65 \pm 1.92$ & $20.73 \pm 2.41$ & $2.33 \pm 0.09$ & $5.69 \pm 0.66$ \\
\hline Pastinaca sativa & $36.01 \pm 3.12$ & $16.20 \pm 1.82$ & $2.43 \pm 0.15$ & $5.36 \pm 0.60$ \\
\hline Pseudotaenidia montana. & $64.05 \pm 5.15$ & $21.32 \pm 2.38$ & $2.10 \pm 0.04$ & $4.67 \pm 0.59$ \\
\hline Sium suave & $63.45 \pm 2.75$ & $36.82 \pm 1.96$ & $1.62 \pm 0.04$ & $11.71 \pm 0.66$ \\
\hline Taenidia Integerrima & $40.18 \pm 4.63$ & $23.21 \pm 1.75$ & $2.96 \pm 0.27$ & $8.23 \pm 0.68$ \\
\hline Thaspium barbinode & $51.53 \pm 5.33$ & $23.02 \pm 2.51$ & $2.24 \pm 0.13$ & $5.37 \pm 0.81$ \\
\hline Zizla aptera & $66.86 \pm 3.70$ & $40.37 \pm 1.67$ & $1.96 \pm 0.08$ & $13.86 \pm 0.47$ \\
\hline zizla aurea & $56.66 \pm 3.67$ & $26.60 \pm 1.23$ & $2.90 \pm 0.10$ & $9.88 \pm 0.33$ \\
\hline
\end{tabular}

'The significance values of the 'T' statistic with $30 \mathrm{df}$ are: $0.05= \pm 2.042$, $0.01= \pm 2.750$.

$2_{T}=1.019$

$3_{T}=2.814$

${ }^{4} \mathrm{~T}=1.937$

${ }^{5} T=2.510$ 
these different growth rates could be due to a variety of factors within the various host plant species. A particular host plant species may be deficient in certain nutrients necessary for proper larval growth and development or may contain various secondary chemicals which deter or inhibit larval feeding or physiologically interfere with the digestion, the assimilation and/or the utilization of food by the larvae.

If the larvae reared on the wild umbellifer species gained less weight because of a behavioral deterence or inhibition of feeding, a reduction in the total food consumed or in the conusmption indices would be observed. However, all larvae on the 32 treatment groups ingested approximately the same total amount of food $(\mathrm{P}<.3)$, and consumed this food at approximately the same rate $(\mathrm{P}<$.I $)$ (Tables 2,3). It thus appears that the observed reduction in growth rate was not due to a purely behavioral response to repellent substances in the leaf material.

Any physiological effect that would significantly reduce larval growth and development would become evident in either the reduced digestibility of the food or in a reduction of the efficiency of conversion of ingested food to larval biomass. In terms of the overall digestibility of the food, cultivated umbellifer species are significantly $(\mathrm{P}<0.05)$ more digestible for the larvae than the weedy umbellifer species (Table 2). Along with this, the efficiency with which larvae utilize ingested matter for the production of biomass is significantly higher $(\mathrm{P}<0.05)$ for larvae reared on cultivated umbellifer species (Table 2). It was also found that a strong correlation exists between the dry weight gained per day by the larvae and the digestibility of the food $(\mathrm{r}=.586,30 \mathrm{df}$. $)$ and the efficiency of conversion of ingested matter $(\mathrm{r}=.7 \mathrm{II}, 30 \mathrm{df}$.). It thus appears that some interference to the digestive processes is occurring in larvae reared on the weedy umbellifer species. This could be due to the action of secondary chemicals, either qualitative, quantitative, or both on the gut lining. This interference with digestion in the gut by the action of plant secondary chemicals has been previously established (Erickson and Feeny 1973).

Once the food material has passed through the gut, all larvae, be they reared on cultivated or wild umbellifers, utilize it for biomass production to the same degree (Table 3 ). A non-significant correlation exists between the efficiency of conversion of digested matter and the amount of weight gained per day $(r=.248,30 \mathrm{df}$.) and the efficiency of conversion of digested matter and the approximate digestibility $(\mathrm{r}=.258,30 \mathrm{df}$. $)$. This suggests that once the food is 
assimilated through the gut wall, there is no further effect on its utilization, which supports the supposition of interference with digestion occurring in the gut of the larvae reared on weedy umbellifer species.

Besides the apparent interference with digestion found in larvae reared on wild or weedy umbellifer species, are there any nutritional differences between the cultivated and wild plant species that may influence overall food utilization? Among the 32 umbellifer species tested, no significant difference was found in the caloric content of the leaf material offered to the larvae (Table I). Thus, in terms of calories all leaves presented to the larvae were of equal value.

It has been suggested that the water content of the host plant would greatly affect the utilization efficiencies. A strong significant difference ( $\mathrm{P}<\mathrm{O}$.OI) exists between cultivated and weedy umbellifer species, with the cultivated species being much higher in water content than the weedy species. A definite negative correlation exists between plant dry matter content and the amount of larval weight gained $(\mathrm{r}=.466,30 \mathrm{df}$.) and plant dry matter content and the utilization of ingested matter ( $r=.7 \mathrm{I}$, 30 df.). It has been shown in this laboratory, that by varying the water content of leaf material, the utilization of food by the cecropia moth, Hyalophora cecropia, is greatly affected (J. M. Scriber, in preparation). This effect was shown in lengthened development times for larvae reared on plants with low water content in which the total food consumed increased but the consumption rate remained relatively constant. In our experiment however, larval developmental times as well as total food consumed did not vary significantly but larval food utilization was affected by the digestibility and the efficiency of conversion of ingested food into larval biomass. It appears from the correlations found that the dry matter content of the umbellifer leaves may have some influence on the larval utilization efficiences to an unknown degree.

The importance of nitrogen for larval growth and development cannot be overemphasized. Friend (1958), House (1961, I962), and Dadd (1973) have discussed the qualitative requirements of proteins and amino acids for larval development. There appears to be an optimal nitrogen level, which varies from species to species, that produces maximal larval growth (Dadd I96r, House I959, Vanderzant 1958). If nitrogen is a limiting factor for larval growth in this species as has been shown for other lepidopterous larvae (Erickson 1972), larvae reared on plant species containing higher 
nitrogen levels should develop at a faster rate and gain more larval biomass. A highly significant difference $(\mathrm{P}<0.05)$ exists in the nitrogen content between cultivated and weedy umbellifer species (Table I). In terms of larval growth rates, a significant correlation exists between the weight gained per day and the nitrogen content of the plant $(\mathrm{r}=.70 \mathrm{I}, 30 \mathrm{df}$.). Cultivated umbellifer species contain approximately $\mathrm{I} \%$ more total nitrogen than weedy umbellifer species, which in terms of protein content means an increase of approximately $6.25 \%$ (Lord 1968 ). This increase in nitrogen protein content would allow larvae to gain more weight per unit of food, thus utilizing their ingested food more efficiently.

The differential growth rates displayed by larvae reared on cultivated and weedy umbellifer species is most likely due to a variety of factors. Cultivated umbellifer species generally appear to be more digestible and more nutritionally adequate for larvae of $P$. polyxenes. Is it possible that through the long history of the domestication and cultivation of plants that man has developed plants more digestible and nutritionally adequate for insects as well as for himself? Organisms have a limited amount of energy to spend and will be selected to partition this energy in different ways depending upon changing environments and physiological conditions (Cody 1966). Any activity of an organism, or more precisely, the energy expenditure for that activity, can be viewed only in relation to all other demands for energy. Wild or weedy umbellifer species are under a constant selection pressure, always adapting to new predators, be they arthropod, vertebrate, or pathogen. Domesticated and cultivated species have been carefully and artificially selected for increased palatibility, yield, and nutritional quantities possibly at the expense of the plant's own defenses. Thus, in producing plants more edible and nutritionally adequate for man, agriculturists have unintentionally made these plants more edible and nutritionally adequate for the insect herbivore. Has man, in a sense, chained himself to the plant, having to provide for the plant's defense through the use of insecticides or through other biological control mechanisms?

\section{ACKNowledgements}

This research was in part supported by Hatch Grant \# I394I3 to Dr. Paul P. Feeny. Dr. Dennis Parnell added a variety of useful comments on the manuscript. 


\section{Literature Cited}

Allard, R. W. 1960. Principles of Plant Breeding. John Wiley \& Sons, Inc., New York. 485 pp.

Allen, M. D. and I. W. Selman. 1955. Egg-production in the mustard beetle, Phaedon cochleariae $\mathrm{F}$. in relation to diets of mineral-deficient leaves. Bull. Entomol. Research 46: 393-397.

Allen, M. D. and I. W. Selman. 1957. The response of larvae of the large white butterfly (Pieris brassicae L.) to diets of mineral-deficient leaves. Bull. Entomol. Research 48: 229-242.

Auclair, J. L., Maltais, J. B. and J. J. Cartier. 1957. Factors in resistance of peas to the pea aphid, Acyrthosiphon pisum (Harr.) (Homoptera: Aphidae). II. Amino acids. Can. Ent. 89: 457-464.

Bernays, E. A. and R. F. Chapman. 1970. Experiments to determine the basis of food selection by Chorthippus parallelus (Zetterstedt) (Orthoptera: Acrididae) in the field. J. Anim. Ecol. 39: 761-776.

Boyd, C. E. 1970. Amino acid, protein and caloric content of vascular aquatic macrophytes. Ecology 51: 902-906.

Breedlove, D. E. and P. R. Ehrlich. 1968. Plant herbivore co-evolution: lupines and lycaenids. Science 162: 671-672.

Briggs, F. N. and P. F. Knowles. 1967. Introduction to Plant Breeding. Reinhold Publishing Corp., New York. 426 pp.

Buttery, R. G., Seifert, R. M., Guadagni, D. G., Black, D. R., and L. C. Ling. 1968. Characterization of some volatile constituents of carrots. J. Agr. Food Chem. 16: 1009-1015.

Chapman, R. F. 1969. The insects, structure and function. American Elsevier Publ. Co., Inc., New York. 819 pp.

Chittenden, F. H. 1909. Some insects injurious to truck crops. II. The celery caterpillar. USDA Ent. Bull. 82: 20-24.

Clarke, G. L. 1946. Dynamics of production in a marine area. Ecol. Monogr. 16: 323-335.

Cody, M. L. 1966. A general theory of clutch size. Evolution 20: 174184.

Dadd, R. H. 1957. Ascorbic acid and carotene in the nutrition of the desert locust, Schistocerca gregaria Forsk. Nature 179: 427-428.

Dadd, R. H. 1961. Observations on the effects of carotene on the growth and pigmentation of locusts. Bull. ent. Res. 52: 63-81.

Dadd, R. H. 1973. Insect nutrition: Current developments and metabolic implications. Ann. Rev. Entomol. 18: 381-420.

Dethier, V. G. 1954. Evolution of feeding preferences in phytophagous insects. Evolution 8: 33-54.

Dethier, V. G. 1970. Chemical interactions between plants and insects. In: Sondheimer, E. and J. B. Simeone (eds.), Chemical ecology. Academic Press, New York and London. pp. 83-102.

Ehrlich, P. R. and P. H. Raven. 1965. Butterflies and plants: a study in co-evolution. Evolution 18: 586-608.

Engelmann, M. D. 1966. Energetics, terrestrial field studies, and animal productivity. In: Advances in Ecological Research. ed. J. B. Cragg. Academic Press, Inc. London and New York. Vol. 3, pp. 73-115.

Erickson, J. M. 1972. The utilization of various Asclepias species by larvae of the monarch butterfly, Danaus plexippus. Psyche 80:230-244. 
Erickson, J. M. and P. Feeny. 1973. Sinigrin: A chemical barrier to the Black Swallowtail Butterfly, Papilio polyxenes. Ecology, 55: 103-111.

Feeny, P. P. 1968. Effect of oak leaf tannins on larval growth of the winter moth Operophtera brumata. J. Insect Physiol. 14: 805-817.

Feeny, P. P. 1969. Inhibitory effect of oak leaf tannins on the hydrolysis of proteins by trypsin. Phytochemistry 8: 2119-2126.

Feeny, P. P. 1970. Seasonal changes in oak leaf tannins and nutrients as a cause of spring feeding by winter moth caterpillars. Ecology 51: 565-581.

Forbes, W. T. M. 1960. Lepidoptera of New York and neighboring states. IV. Cornell U. Agr. Exp Stat. Mem. \# 371. 188 pp.

Fraenkel, G. 1953. The nutritional value of green plants for insects. Trans. 9th Intern. Congr. Entomol. 2: 90-100.

Fraenkel. G. 1969. Evaluation of our thoughts on secondary plant substances. Ent. exp. \& appl. 12: 473-486.

French, D. H. 1971. Ethnobotany of the Umbelliferae. In: V. H. Heywood (ed.). The biology and chemistry of the Umbelliferae. Academic Press, Inc., New York. p. 385-412.

Friend, W. G. 1958. Nutritional requirements of phytophagous insects. Ann. Rev. Ent. 3: 57-74.

Gerking, S. D. 1962. Production and food utilization in a population of bluegill sunfish. Ecol. Monogr. 32 : 31-78.

Gill, J. S. and C. T. Lewis. 1971. Systematic action of an insect feeding deterrent. Nature 23 2: 402-403.

Gilmour, D. 1961. The biochemistry of insects. Academic Press, New York and London.

Gordon, H. T. 1959. Minimal nutritional requirements of the German roach, Blatella germanica L. Ann. N.Y. Acad. Sci. 77: 290-351.

Guenther, W. C. 1965. Concepts of Statistical Inference. McGraw-Hill Book Co., New York. 353 pp.

Harlan, H. V. 1957. One man's life with barley. Exposition Press, New York. $373 \mathrm{pp}$.

Havens, J. N. 1792. Observations on the Hessian fly. Soc. Agr. New York, Pt. 1: 89-107.

Hiratsuka, E. 1920. Researches on the nutrition of the silk worm. Bull. ser. Exp. Sta. Japan, 1: 257-315.

Holloway, J. K. 1964. Projects in biological control of weeds. In: DeBach, P. (ed.) Biological control of insect pests and weeds. Chapman and Hall, London. pp. 650-670.

Hopkins, F. G. 1912. Feeding experiments illustrating the importance of accessary factors in normal dietaries. J. Physiol., Lond. 44: 425-460.

House, H. L. 1959. Nutrition of the parasitoid Pseudosarcophaga affinis (Foll.) and other insects. Ann. N. Y. Acad. Sci. 77: 394-405.

House, H. L. 1961. Insect nutrition. Ann. Rev. Entomol. 6: 13-26.

House, H. L. 1962. Insect nutrition. Ann. Rev. Biochem. 31: 653-672.

House, H. L. 1965. Effects of low levels of the nutrient content of a food and of nutrient imbalance on the feeding and the nutrition of a phytophagous larva, Celera euphorbiae (L.) (Lepidoptera: Sphingidae). Can. Ent. 97: 62-68.

Hovanitz, W. and V. C. S. Chang. 1962. The effect of various food plants on survival and growth rates of Pieris. J. Res. Lepidoptera 1: 21-42. 
Janzen, D. H. 1969. Seed-eaters versus seed size, number. toxicity and dispersal. Evolution 23: 1-27.

Janzen, D. H. 1971. Escape of juvenile Dioclea megacarpa (Leguminosae) vines from predators in deciduous tropical forest. Amer. Nat. 105 : $97-112$.

Jermy, T. 1966. Feeding inhibitors and food preference in chewing phytophagous insects. Ent. exp. \& appl. 9: 1-12.

Johnson, B. 1953. The injurious effects of the hooked epidermal hairs of French beans (Phaseolus vulgaris L.) on Aphis craccivora Koch. Bull. ent. Res. 44: 779-788.

Kaplan, L. and R. S. MacNeish. 1960. Prehistoric bean remains from caves in the Ocampo region of Tamaulipas, Mexico. Bot. Mus. Leaflets, Harvard Univ. 19: 33-56.

Kasting, R., Andersson, J., and E. von Sydow. 1972. Volatile constituents in leaves of parsley. Phytochemistry 11: 2277-2282.

Kingsbury, J. M. 1964. Poisonous plants of the United States and Canada. Prentice-Hall, Inc., Englewood Cliffs, New Jersey. 626 pp.

Kozlovsky, D. G. 1968. A critical evaluation of the trophic leel concept. I. Ecological efficiencies. Ecology 49: 48-60.

Lafon, M. 1951. Quelques documents sur l'appetit et la consommation alimentaire chez les insectes. Ann. Nutr., Paris, 5: 485-504.

Legay, J. M. 1958. Recent advances in silkworm nutrition. Ann. Rev. Ent. 3 : 75-86.

Levinson, Z. H. 1962. The function of dietary sterols in phytophagous insects. J. Insect Physiol. 8: 191-198.

Lewis, P. and D. Rubenstein. 1971. The human body. Bantam Books, Inc., New York. 159 pp.

Lord, C. (ed). 1968. Biochemist's handbook. Spon, London. 1192 pp.

Merz, E. 1959. Pflanzen und Raupen. Über einige Prinzipien der Futterwahl bei Grosschmetterlingsraupen. Biol. Zbl. 78: 152-188.

McKenzie, H. A. and H. S. Wallace. 1954. The Kjeldahl determination of nitrogen: A critical study of digestion conditions - temperature, catalyst, and oxidizing agent. Aust. J. Chem. 7: 55-70.

Muenscher, W. C. 1951. Poisonous plants of the United States. The MacMillan Co., New York. 277 pp.

Odum, E. P. 1971. Fundamentals of ecology. W. B. Saunders Company, Philadelphia, Pennsylvania. 3rd edition, $574 \mathrm{pp}$.

Odum, H. T. 1957. Trophic structure and productivity of Silver Springs, Florida. Ecol. Monogr. 27: 55-112.

Painter, R. H. 1951. Insect resistance in crop plants. MacMillan Co., New York. 520 pp.

Pathak, M. D. 1969. Stem borer and leaf hopper-plant hopper resistance in rice varieties. Ent. exp. \& appl. 12: 789-800.

Pearson, E. O. 1958. The insect pests of cotton in tropical Africa. Eastern Press. London. 355 pp.

Phillipson, J. 1964. A miniature bomb calorimeter for small biological samples. Oikos 15: 130-139.

Phillipson, J. 1966. Ecological energetics. William Clowes and Sons, Ltd., London. $57 \mathrm{pp}$.

Polunin, N. 1960. Introduction to Plant Geography and some related sciences. McGraw-Hill Book Co., Inc. New York. 
Snedecor, G. W. and W. G. Cochran. 1967. Statistical Methods. Iowa State University Press, Ames, Iowa. 593 pp.

Snelling, R. O. 1941. Resistance of plants to insect attack. Bot. Rev. 7 : 543-586

Stahl, E. 1888. Pflanzen und Schnecken. Biologische Studie über die Schutzmittel der Pflanzen gegen Schneckenfrass. Jena. Z. Med. Naturw. 22: $557-684$.

Tanton, M. T. 1962. The effect of leaf 'toughness' on the feeding of larvae of the mustard beetle. Ent. exp. \& appl. 5: 74-78.

Taylor, L. R. 1959. Abortive feeding behavior in a black aphid of the Aphis fabae group. Ent. exp. \& appl. 2: 143-153.

Thorsteinson, A. J. 1960. Host selection in phytophagous insects. Ann. Rev. Ent. 5: 193-218.

Vanderzant, E. S. 1958. The amino acid requirements of the pink bollworm. J. Econ. Ent. 51: 309-311.

Waldbauer, G. P. 1960. Feeding and growth on solanaceous and nonsolanaceous plants by normal and maxillectomized larvae of the tobacco hornworm, Protoparce sexta (Johan.) (Lepidoptera: Sphingidae). Ph.D. thesis. University of Illinois, Urbana, Illinois. $134 \mathrm{pp}$.

Waldbauer, G. P. 1964. The consumption, digestion, and utilization of solanaceous and non-solanaceous plants by larvae of the tobacco hornworm, Protoparce sexta (Johan.) (Lepidoptera: Sphingidae). Ent. exp. \& appl. 7 : 253-269.

Waldbauer, G. P. 1968. The consumption and utilization of food by insects. Adv. Insect Physiol. 3: 229-282.

Waldbauer, G. P. and G. Fraenkel. 1961. Feeding on normally rejected plants by maxillectomized larvae of the tobacco hornworm, Protoparce sexta (Lepidoptera, Sphingidae). Ann. Ent. Soc. Amer. 54: 477-485.

Whittaker, R. H. and P. P. Feeny. 1971. Allelochemics: Chemical interactions between species. Science 171: 757-770.

Williams, C. M. 1970. Hormonal interactions between plants and insects. In: Sondheimer, E. and J. P. Simeone (eds.). Chemical ecology. Academic Press, New York and London. pp. 103-132.

Williams, P. C. 1964. The calorimetric determination of total nitrogen in feeding stuffs. Analyst 89: 276-281. 

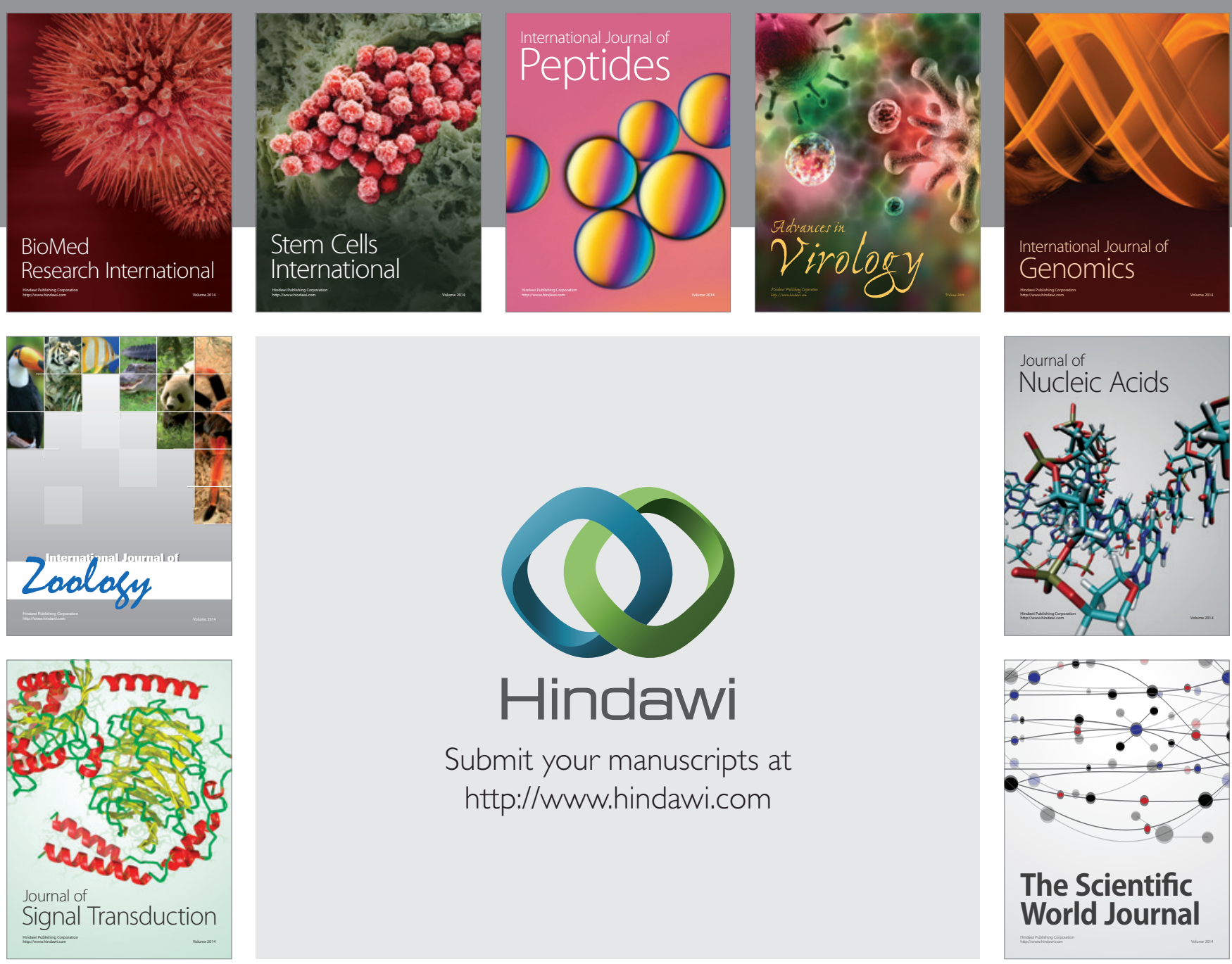

Submit your manuscripts at

http://www.hindawi.com
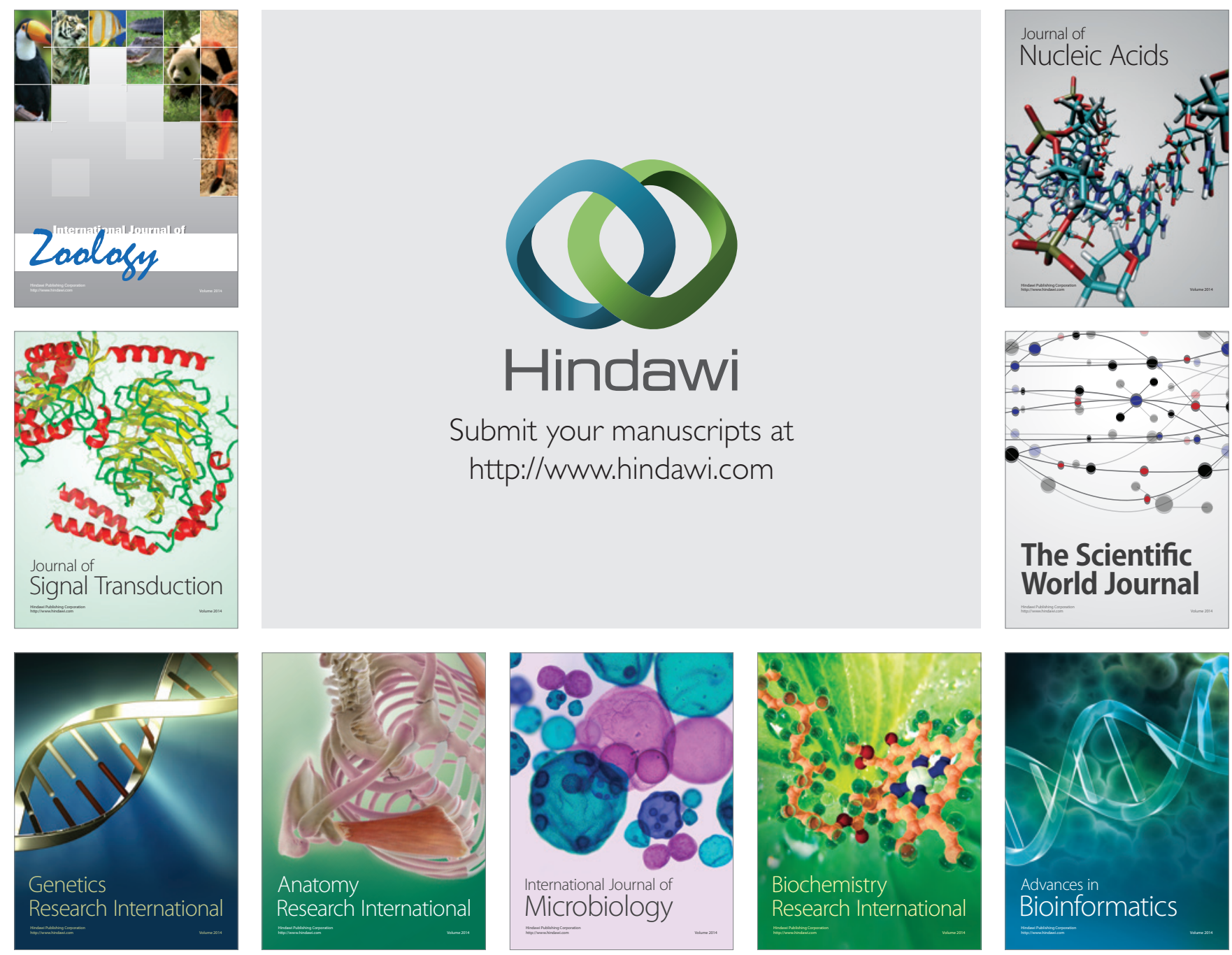

The Scientific World Journal
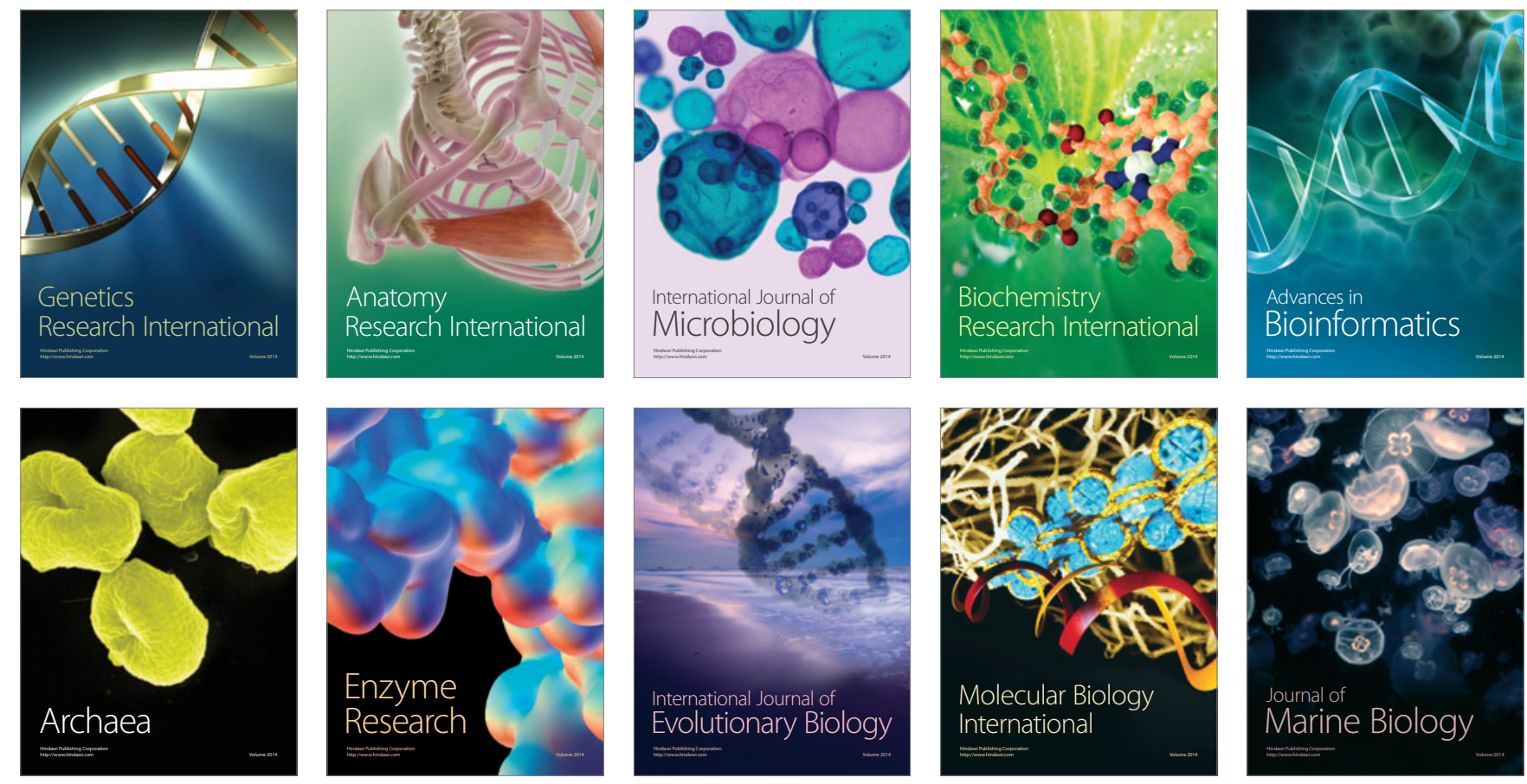